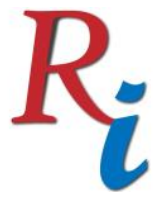

Asia Proceedings of Social Sciences

(APSS)

www.readersinsight.net/APSS

\title{
CULTURE INFLUENCE TOWARDS INTENTION OF TAX NON- COMPLIANCE AMONG SME OWNERS
}

\section{Nor Zuhairatun Md Radzi}

Kulliyyah of Muamalat and Management Sciences

Universiti Islam Antarabangsa Sultan Abdul Halim Mu'adzam Shah Malaysia

*Corrosponding author's Email: norzuhairatun@unishams.edu.my

Peer-review under responsibility of 5 th $^{d}$ Asia International Conference 2019 Scientific Committee http://connectingasia.org/scientific-committee/

(C) 2019 Published by Readers Insight Publisher, lat 306 Savoy Residencia, Block 3 F11/1,44000 Islamabad. Pakistan,

editor@readersinsight.net This is an open access article under the CC BY-NC-ND license (http://creativecommons.org/licenses/by-nc-nd/4.0/). 


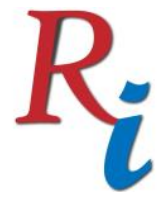

\section{Asia Proceedings of Social Sciences}

(APSS)

www.readersinsight.net/APSS

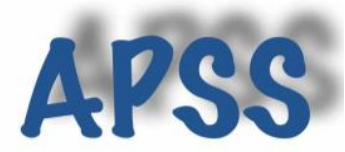

\section{A b s tract}

The importance of SME as backbone of Malaysia in generating national income is undoubtedly. However, little has been focused on culture influence as one of the determinants of tax non-compliance. With the multicultural society which having different culture, belief and value, it is important to examine culture influence towards tax non-compliance. Therefore, this study attempts to examine the influence of culture towards intention of tax non-compliance using the framework of Hofstede's Cultural Dimensions Theory as basis of the study. The survey has collected data of 248 usable SME owners from northern region of Peninsular Malaysia. Findings reveal that power distance, individualism, masculinity, uncertainty avoidance and long-term orientation are significantly related with intention of tax non-compliance. Suggestions for policy makers and future researchers are also highlighted.

Keywords: Culture Influence, Hofstede's Cultural Dimensions Theory, Intention, SME Owners, Tax Non-Compliance

\section{Rese a r ch H igh I ight s}

SMEs as backbone of Malaysia have leads the economic local and export demand with a contribution up to 99.2 percent of businesses and companies in Malaysia (Kamaruddin, 2014). Its contribution towards the GDP has increased from 37.8 percent to 38.3 percent and the local sectors believed to grow higher concurrent with the contribution rate of SME towards nation to achieve more than RM800 billion or 40 percent of the GDP by 2020 . However, SME owners tend to engage in tax non-compliance due to huge opportunities involving in cash business transactions and avoid cash declaration (Mohamad, Zakaria and Hamid, 2016) especially because their actions appeared to be mostly overlooked by the tax authority (Mohd Ali, 2013). The serious problem of tax non-compliance among SME owners have caught attention from tax authorities, academician and non-governmental organizations all over the world (Newman, Mwandambira, Charity and Ongayi, 2018). Nevertheless, little has been focused on culture influence in explaining tax non-compliance among SME owners. According to Roth, Scholz and Whitte (1989), culture influence is very important in explaining tax non-compliance since culture itself may reflected taxpayers' values and norms 


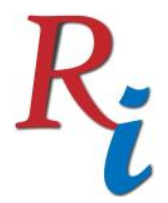

\section{Asia Proceedings of Social Sciences}

(APSS)

www.readersinsight.net/APSS

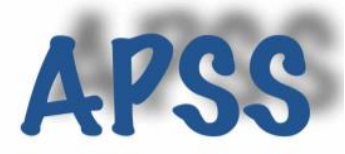

which constantly practiced in their daily life which later can shape their attitude towards noncompliance, either to increase or decrease tax non-compliance.

\section{Research Objectives}

The objective of the study is to examine the influence of culture on the intention of tax noncompliance among SME owners. To do so, five-dimensional measure of culture in Hofstede's Cultural Dimensions Theory known as power distance, individualism versus collectivism, masculinity versus femininity, uncertainty avoidance and long-term versus short-term orientation used in this study.

\section{Methodology}

A survey were self-administered using a structured questionnaire, adapted and modified from instrument used by Hamid (2013) and Minkov and Hofstede (2012) to suit to SME owners in measuring culture towards intention of tax non-compliance. A five item Likert scale will be used and 5 score will be given for "strongly agree" and 1 for "strongly disagree". The questionnaire randomly personal distributed and collected from the SME owners from five major urban towns located in the northern region of Peninsular Malaysia including Kangar, Alor Setar, Sungai Petani, Kulim and George Town. A total of 500 samples were distributed and 248 were usable or response rate of 49.6 percent.

\section{Results}

The data has been conducted accordingly and analyzed using Statistical Package for the Social Science (SPSS) $25^{\text {th }}$ version. The histogram residual plot defines that data are normal as well as normal probability plots and scatterplot defines that data are linear and fit for further analysis. Additionally, the tolerance values and variance inflation factors indicates that there is no multicollinearity issue. The R-square, which considered as moderate, explains that power distance, individualism, masculinity, uncertainty avoidance and long-term orientation can explain 36.0 percent of the variance in intention of tax non-compliance. Finding reveals that the relationship between power distance, indvidualism, masculinity, 


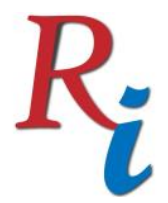

\section{Asia Proceedings of Social Sciences}

(APSS)

www.readersinsight.net/APSS

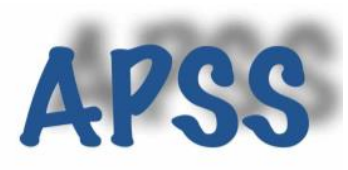

uncertainty avoidance and long-term orientation with intention of tax non-compliance are significant, thus provide support to hypotheses of this study.

\section{Findings}

Finding suggests that all of the determinants do directly influence SME owners towards intention of tax non-compliance. Power distance, uncertainty avoidance and long-term orientation cultural values reveal a positively significant relationship towards intention of tax non-compliance. Meanwhile, the relationship between individualism and masculinity cultural values with intention of tax non-compliance found to be negatively significant. Study concludes that SME owners with lower power distance and uncertainty avoidance, more to individualist and masculinity cultural values and long-term oriented tend not to engage in tax non-compliance.

\section{References}

Hamid, S. A. (2013). Tax compliance behaviour of tax agents: A comparative study of Malaysia and New Zealand. PhD Thesis, University of Canterbury, New Zealand.

Kamaruddin, S. B. 2014. PKS adalah pemacu ekonomi masa depan negara. Retrieved October 15, 2016, from www.ukm.my/news/arkib/year-2014/ogos-2014/pks-adalahpemacu-ekonomi-masa-depan-negara/

Minkov, M. \& Hofstede, G. (2012). Hofstede's fifth dimension: New evidence from the World Values Survey. Journal of Cross-Cultural Psychology, 43(1), 3-14.

Mohamad, A., Zakaria, M. H. \& Hamid, Z. (2016). Cash economy: Tax evasion amongst SMEs in Malaysia. Journal of Financial Crime, 23(4), 974-986.

Mohd Ali, N. R. (2013). The influence of religiosity on tax compliance in Malaysia. PhD Thesis, Curtin University.

Newman, W., Mwandambira N., Charity, M. \& Ongayi, W. (2018). Literature review on the impact of tax knowledge on tax compliance among small medium enterprises in a developing country. International Journal of Entrepreneurship, 22(4), 1-15.

Roth, J. A., Scholz, J. T., \& Whitte, A. D. (1989). Taxpayer compliance: An agenda for 


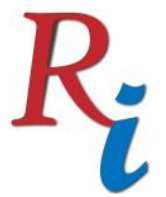

\section{Asia Proceedings of Social Sciences}

(APSS)

www.readersinsight.net/APSS

research. Philadelphia: University of Pennsylvania Press.

Author's Biography

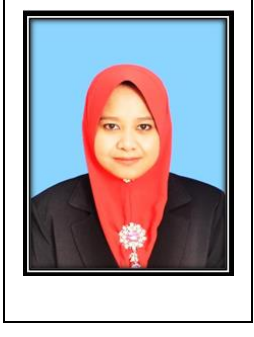

Nor Zuhairatun Md Radzi is a lecturer at Department of Accounting, Kulliyyah of Muamalat and Management Sciences, Universiti Islam Antarabangsa Sultan Abdul Halim Mu'adzam Shah. She holds a Master degree from Universiti Utara Malaysia and a Bachelor degree from Universiti Putra Malaysia. Currently, she is pursuing PhD at Tunku Puteri Intan Safinaz School of Accountancy, Universiti Utara Malaysia 